\title{
Human Rights in China: An Alien Element in a Non- Western Culture?
}

\section{Heiner Roetz}

China and human rights is a topic that time and again sparks off the debate on the universality or relativity of ethical norms. It also has bearing on the question of the global legitimacy of modernity, at least if we follow the classic self-understanding of modernity in terms of the implementation of the principle of "free subjectivity" (Hegel) including guarantees of subjective rights and participative political institutions. Against this understanding, alternative forms of a multiplicity of "modernities" substantially different from the "Western" model have been proposed which would also be marked by another relationship to human rights. This would imply that "our" notion of human rights is only a specific value that cannot be generalized without imposing an excessive demand on other cultures. At least, culture specific preferences between the routinely distinguished three "generations" or "dimensions" of human rights - civil rights, social rights, and collective rights - would be possible: the traditional and still prevalent "Western" emphasis on civil rights with the free individual as its point of departure would not be the only legitimate one.

In this debate, the universalists advocate the primacy of right over culture. In this case, human rights, unreduced to collective rights, would be the highest norm that if necessarily trumps cultural particularities. The culturalists, reversely, regard culturespecific value systems as the ultimate normative axioms. The classical credo in this direction was formulated by the American Anthropological Association in 1947, when it warned against the impending proclamation of the "Universal Declaration of Human Rights" by the United Nations General Assembly: "Standards and values are relative to the culture from which they derive so that any attempt to formulate postulates that grow out of the beliefs or moral codes of one culture must to that extent detract from the applicability of any Declaration of Human Rights to mankind as a whole." (American Anthropological Association 1947:539) This seems to be, more or less, still the majority conviction in cultural studies, with a deep impact on sinology.

A third group that could be called the historists would like to leave the matter to the course of history. They refer to the "autopoiesis" of social and political systems or to the change brought about by commerce (as in the German proverb "Handel bringt Wandel"), as circles interested in unhampered market economy gladly attest. Culturalists and historists often take the position of legal positivism-what is valid is decided by the different constitutions or juridical systems.

Not only has the normative preference that one should choose with regard to human rights been a subject of controversy, but also the assessment of China in this context. How to evaluate China is important because of the political and economic weight of the country and its claim to represent an original and time-honoured cultural heritage 
in its own right. As the alleged antipode of the West, China has served as an acid test for the universality of norms already for some centuries.

As a matter of fact, the notion of human rights has not been brought forward in pre-modern China, but was imported as an originally foreign idea from the West in the $19^{\text {th }}$ century. Strictly speaking, it had no lasting impact on Chinese politics, except for the situation in Taiwan in the last two decades after the end of martial law. Against this background, it has often been maintained that there is a basic repugnancy between human rights and "the" Chinese culture. However, before invoking the argument of culture, the failure of human rights can be explained by a number of historical reasons. It was not pushed by the West itself where legal positivist, Darwinist and often enough anti-modern ideologies were dominant, not to mention its colonial policy aiming at the domination and exploitation rather than political modernization of the rest of the world. A striking example is Hong Kong: Efforts to democratize the "crown colony" can essentially be found only in the final years of British rule, when they were cheap and noncommittal (von Senger 1997). Western handling of human rights has contributed more to discrediting them than their alleged incompatibility with other traditions, and seeing Western politicians playing the human rights missionary creates an unpleasant aftertaste. In China itself, the idea of human rights was ground down in an unsupportive atmosphere of struggle for national survival and civil war. ${ }^{1}$ Today, it is officially not altogether rejected but tailored to the needs of the dictatorial system.

The stance of the People's Republic on human rights is a mixture of the abovementioned universalist, relativist and historist positions, with a distinct relativistichistoristic tendency. It is true that human rights were included in the State Constitution in 2004 in the sentence "The state respects and preserves human rights" (Article 33), although politically restricted by the Preamble and Article 51.2 Interestingly enough, the protection of human rights was added to the Constitution together with the right to "lawful" private property (Article 13). China officially regards their formulation as a sign of progress relevant for all mankind. However, it insists on its own reading. According to this reading, as laid out in the famous White Book of 1991 "The Situation of Human Rights in China" (Guowuyuan xinwenbangongshi 1991) and many other documents to follow, the most fundamental human right is the "right to subsistence" (shengcunquan). The practical realization of this right presupposes the collective "right to development" (fazhanquan) in trusteeship of the state. This, again, generates the state's "right to sovereignty" (duliquan), with the duty of non-intervention on the part of other states. Thus the Chinese human rights project ends up in the right of the state as a developmental agency in the interest of the collective rather than in guaranteeing

${ }^{1}$ For the Chinese discussion of human rights in the last century cf. Angle and Svensson 2001.

2 The Preamble still defines the political system as a "democratic dictatorship of the people" under the leadership of the Communist Party. Article 51 provides that "the exercise by citizens of the People's Republic of China of their freedoms and rights may not infringe upon the interests of the state, of society and of the collective, or upon the lawful freedoms and rights of other citizens." (Constitution of the People's Republic of China, http://english peopledaily com cn/constitution/constitution.html) 
rights to individuals against the state. Criticism of China's human rights record in the name of individual rights to political participation and legal protection is regularly denounced as an attempt to hamper the country's development. Development as such is claimed to be in the interest of the great majority of the people and in this sense to be per se democratic. The Western equivalent to this kind of reasoning is that the best way to promote political reform in China is the uninhibited unfolding of the market economy without making too much fuss about present human rights abuses. However, to make human rights an appendix of economic growth, a logic which is curiously reflected in the 2004 amendment of the Chinese Constitution, would mean to regard the human being as a means for realizing profit rather than an end in itself. This corresponds to the reduction of the holder of rights to a possessive individualist, to which I will return.

China defends its position by pointing out the historical situation of the country and the practical difficulties in governing it. However, it also appeals to the "cultural factor" (wenhua yinsu) with arguments reminiscent of the "Asian values" campaign of the Southeast-Asian states in the 1990s. An excessive individualism, a one-sided insistence on rights over duties and an "atomistic" understanding of society and thus a view of the human being that would prioritize individual over collective rights are rejected as Western-specific and incompatible with the endogenous value system. The emphasis on collective rights together with the strong position of the state would thus have a cultural backing. This standpoint also has an impact on bioethics: Here, we find the argument that because a human only exists as a member of a community, which means in a strict sense only after birth, consumptive embryo research, to give an example, would not pose an ethical problem in China. Thus, one and the same "relational" view of the human being would justify an illiberal conception of politics on the one hand and a liberal attitude towards biotechnology on the other (Roetz 2009a).

It has to be stressed that these positions are not unanimously shared in China, ${ }^{3}$ although they are often presented as a cultural consensus. In Western Chinese studies, they have again and again met with voluntary as well as involuntary support. Some Sinologists feel even greater discomfort than the Beijing government when it comes to finding a place for individual rights in Chinese culture. It has been maintained, for example, that in China there is no general notion of a human being in the first place, but only the notion of different social roles like father, mother, son, wife, ruler etc. Therefore, the abstract conception of a "subject" as the bearer of corresponding general "subjective" rights would not exist. The German Sinologist Wolfgang Bauer has declared that individual rather than collective rights would be incompatible with the "traditional Chinese point of view", since the human being is "primarily defined by his or her membership in a certain social community, an estate or a 'class'." (Bauer 1994:54) Henry Rosemont has argued that in Confucianism humans are nothing but the "totality of roles" they live "in relation to specific others"- they are these roles rather than 
performing them (Rosemont 1988:177). David Hall and Roger Ames, again, have stressed that in Confucianism "in the absence of the performance of these roles, nothing constituting a coherent personality remains: no soul, no mind, no ego, nor even an I know not what." (Hall and Ames 1998:209) Ames also maintains that "in the Chinese tradition humanity is not essentialistically defined," but "understood as a progressive cultural achievement". This would imply that "those who violate social relations and the values they embody are truly brutes," rather than humans who still deserve respect (Ames 1988:202,203). In such assessments, "Chinese" is normally identified with "Confucian" in a rough sense, and there is little distinction made between pre-modern and modern China. Instead, what is regarded as traditional Confucian attitudes is identified as the still prevalent true Chinese "habits of the heart".

Do we have to come to the conclusion, then, that there are definite "cultural limits for the Western form of legitimizing and limiting state power by inalienable rights," (Müller 1997:283) with the result that from a universalistic point of view Chinese culture has to be overcome, or, from a relativistic point of view, the universality claim of human rights has to be discarded? I suppose that there is a third way, because the picture is more complex on both the Western and the Chinese side. Human rights universalism is neither the quintessence of the West nor is it the necessary adversary of Chinese culture.

As to the West, the idea of human rights was not the logical culmination of an indigenous cultural dynamics. It was the outcome of a crisis of the traditional outlook on the world that tore Europe apart when the Christian ordo collapsed in disastrous religious civil wars, clashes between the emerging nation-states, the rise of political absolutism, and, last but not least, the breaking through of the limits of the closed Occidental world in the Renaissance, the age of discoveries (Roetz 2002). It is true that the human rights idea is a product of the West, although its history cannot be sufficiently described as exclusively "Western", and Confucianism by its influence on the European Enlightenment already has some share in it. ${ }^{4}$ The way to it has been paved by, among others, Christian theologians like Francisco de Vitoria and Francisco Suárez of the school of Salamanca, and it can in retrospect be related to central elements of the Jewish-Christian tradition like the view of man as God's image (imago dei) as one source of the idea of human dignity, and monotheism as one source of the claim to universality. Still, both these aspects need to be qualified and are open to divergent developments. Man's likeness to God is restricted by his original sinfulness. The monotheistic claim to universality, again, could lead into repressive uniformity rather than tolerance. This was even the most important negative reason — to an extent unknown in China — for demanding the right to the freedom of conscience. It is symptomatic that the fiercest enemies of human rights can be found among the popes of the $19^{\text {th }}$ century, and that the

4 Zhang Junmai has argued that China has actually contributed to the history of human rights, since, as he says, the "Declaration of the Rights of Man and of the Citizen" of the French Revolution was indirectly inspired by the ancient Confucian Mengzi (Zhang 1981:386). Cf. for this topic Roetz 2011:273-276. 
Catholic and Protestant churches have remained reserved about this subject in the name of the Christian tradition until the middle of the last century (Schrey 1983, Walf 1990). One need not follow Sun Yatsen's claim that China's historical problem was an overabundance rather than lack of freedom (Sun 1973:678-679), which promoted the illfated engineering-understanding of politics among large parts of the modern Chinese elites. But religious tutelage of the aggressive European type was certainly missing in pre-modern China.

The historical attitude of Christianity shows that the final success of the idea of human rights is at least as much due to a departure from the European tradition as it is due to its latent potentials. I assume that a similar ambivalence applies for any culture that has to find new normative bases when confronted with the dissolution of transmitted contexts and world-views, as is the case all over the world in the age of modernity. It is at least an option in this situation, to try to critically reconstruct a cultural tradition in a way that is accommodating and not repugnant to human rights, rather than altogether discard or conservatively reinstall it. The philosophical justification of the human rights idea as well as the commitment to a human rights policy do not necessarily presuppose such reconstructions - one can cherish human rights for their own sake simply because the idea is convincing in itself, without making a detour through a cultural tradition. Human rights, after all, are themselves creating culture rather than merely being its offspring; what really matters is not the cultural heritage, but the actual practice. Still, if such reconstructions were not possible in principle, the idea would be suspended in mid air and could no longer be shown as being rooted in the basic structures of human social existence as such, independent of the particularity of a specific culture like the Western one (see below). In any case, such reconstructions are of great political advantage inasmuch as they can foster the intercultural acceptance of the human rights idea through "anamnetic effects" of re-cognition and dispel the argument of threatened "cultural identity". I assume that this applies to any culture, and it also applies to China. The principal tension between a "modern" and a "traditional" world notwithstanding, rather than setting the Chinese cultural tradition against the mentioned classical understanding of modernity, one can search for the anticipations of modernity in this tradition itself. As I see it, the most important source for such an endeavor is the philosophy of the "axial age" (Jaspers), intellectually the main founding phase of the Chinese civilization.

In the "axial age", China went through an epoch of early enlightenment in the sense of a reflective disassociation from everything hitherto valid and a breakthrough towards "postconventional" (Kohlberg), "decentered" (Piaget, Habermas) or "second order" (Popper) thinking (Roetz 1993, Bellah 2011: China chapter, Roetz 2012). Since then, China has possessed a textually fixed and transmitted stock of critical consciousness, the potentialities of which have historically never been exhausted and are still at hand. This above all refers to two domains of postconventional thinking which have become part of the Chinese intellectual heritage and furnish proof that claiming the general incompatibility of "Chinese culture" with the aforementioned modern "princi- 
ple of subjectivity" would lag behind constituent elements of this culture itself: The critique of power and the detachment from tradition.

Whereas the critique of power contains material aspects that can underpin the modern ideas of human rights and dignity, the critique of, or detachment from, tradition contains formal or meta-aspects that from the beginning contradict any exclusivist reification of culture against those ideas. These points, in particular the second one, have remained underexposed in Chinese studies due to a widespread hermeneutics of contrast - as against a hermeneutics of accommodation - dating back to Hegel's and Weber's influential picture of China as the retarded counter-world of the developed West. The culturalist and postmodernist turns of the last decades have basically accepted the content of this conviction and have only replaced the negative assessment by a positive or neutral one. In East Asia itself, after a period of hypercriticism of the traditional culture following the downfall of the Chinese empire, to reconstruct the indigenous potential for modernization has been the endeavor of "New Confucian" philosophers like Mou Zongsan, Zhang Junmai (Carsun Chang) or, in the next generation, Lee Ming-huei (Li Minghui) (Li 2002), who have rediscovered the critical spirit of Confucian ethics after the end of its liaison with the old political system. The same applies to Deng Xiaojuns independent attempt to show the "logical link between Confucian and democratic thought" (Deng 1995), or to Yu Kam Por's (Yu 2005) and Nie Jingbao's (Nie 2001) interpretation of the Chinese philosophical tradition as supportive of the idea of individual human rights, to mention only some examples. To remind of authors like these is important in a time when Confucianism is again being instrumentalized to legitimize an authoritarian dictatorship.

In what follows, I will discuss some aspects of the critique of tradition and the critique of power mentioned above inasmuch as they might be of relevance to the search for a virtual Chinese prehistory of the human rights idea.

Ideal-typically speaking, culturalism makes two claims: the empirical claim that there is a certain essence of a culture with a specific system of values in its center, and the normative claim that one should safeguard and endorse this essence. Ironically enough, the questioning of both claims is part and parcel of most cultural traditions themselves. In China, the corresponding step is constitutive of the very coming into existence of Chinese philosophy itself, which was the answer to the deep crisis and breakdown of tradition in the middle of the last millennium B.C. This formative experience, which leads into the "axial age", is reflected in an impressive series of antitraditional arguments brought forward in the philosophical classics. They call into question the reliability and validity of appeals to tradition by logical (tradition presupposes innovation), ontological (the true cannot be transmitted), epistemological (the past is not clearly recognizable), historical (times have changed), empirical (tradition is too heterogeneous), ethical (traditional ways of life can contradict moral norms) and anti-ideological (traditions can be forged) considerations. ${ }^{5}$ They thus express the insight

${ }^{5}$ For a detailed analysis of the respective arguments cf Roetz 2005 and 2009. 
that a tradition is no unequivocal and authoritative entity, but needs interpretation and justification by some other criteria in order to be appropriated or, as the case may be, rejected. It is pointed out, for example, that following established ways of life may be equivalent to practicing cannibalism, infanticide, and geronticide, thus contradicting the moral principles of humaneness and justice. 6 New normative criteria are formulated that no longer take their orientation from the past, with practical consequences in the $3^{\text {rd }}$ century B.C., when a novel political system, the centralized bureaucratic state, replaces the old feudal order. Sanctifying tradition is compared to throwing a baby into a river, just because the father was a good swimmer (Lüshi chunqiu 15.8:178). Correspondingly, there is a shift in the political focus away from established norms (cheng fa) to be endorsed to formal procedures how to establish norms (suo yi cheng fa) (Ibid.:177). ${ }^{7}$ This search reaches its climax in the postulation of the primacy of the better argument without the further consent of another authority in the Mozi:

"Humane persons inform each other of the reasons why they choose or reject something or why they find something right or wrong. He who cannot bring forward reasons follows the one who brings forward reasons. He who has no knowledge follows the one who has knowledge. He who has no arguments submits to the other, and when he sees something good, he will change his position accordingly. Why then should they [quarrel]?" (Mozi 39:182)8

The problematizing of and turning away from tradition has not only constituted a specific meta-tradition of its own, but it has directly influenced most of the fundamental issues in the history of Chinese philosophy. The existence of such a "second order" tradition, under pre-modern conditions surely beside the mainstream, takes cultural essentialism to absurdity, since it shows the critical attitude towards tradition to be part of that tradition itself. It not only provides scope for the new-like the idea of human rights - by precluding its rejection on grounds of being incompatible with the old. Its decentered, detached perspective also has an intrinsic affinity to the inherent universalism of the idea of human rights, because it formally shares their context- and culturetranscending nature. Any appeal to a so-called "cultural identity" that does not take into account this non-traditional aspect of tradition would undermine what it claims to protect.

${ }^{6}$ Mo Di ( $5^{\text {th }}$ century B.C.) confronts the proponents of funeral rites, which regard these as the traditional "way of the sage kings," with the argument: "This can be called to consider a habit as convenient and regard custom as a norm for what is just. In ancient times, there was a land named Kaishu east of Yue. Right after birth, the people dismembered the firstborn child and ate it, saying that this was propitious for the younger brothers. When the grandfather died, they loaded the grandmother on their back and abandoned her, saying that they could not live together with the wife of a ghost. The superiors regarded this as the correct order, and the people saw it as a custom. Thus they carried on practicing these things and did not give them up. But how could this, in fact, be the way of humaneness and justice? This means to consider a habit as convenient, and to regard custom as a norm for what is just." (Mozi 25:115-116)

7 Cf. Roetz 2009:367.

8 Cf. for this point Roetz 2012:264-265. 
Even in the center of the one school routinely associated with traditionalism, Confucianism, we find the element of detachment from the old. This refers above all to two of the most conspicuous elements of early Confucian ethics: Confucius's (551-479) Golden Rule and Mengzi's (370-290, latinized Mencius) moral anthropology. According to Confucius, the Golden Rule $(s h u)$ - "What you do not wish done to yourself do not do to others"-fulfills the requirement of a general maxim that "consists of just one word and for this reason can be practiced throughout one's life." (Analects/Lunyu 15.24) It only presupposes the thought experiment of ego taking on the role of alter on the basis of generalized human needs, irrespective of the values of concrete contexts or a specific tradition. The locus of the Golden Rule is the here and now of formal reflection. It paves the way for the moral anthropology formulated by the Confucian Mengzi, which is likewise based on immediacy rather than history - the immediacy of the spontaneous impulse and the intuitive "good knowledge" (liang zhi) of the moral disposition (xing) (see below). It is not by accident the Golden Rule as well as Mengzi's anthropology, both of which stand in another time paradigm than the paradigm of traditional thinking, also deliver the foundations of the Confucian critique of power. This critique refers on the one hand to the expectation of reciprocity between the ruler and the ruled and on the other hand to the respect for the dignity of a human as a moral being different from a brute.

As to reciprocity, cultural anthropology has shown it to be the most important mechanism of integration of the early societies before the emergence of the state (Mauss 1966, Lévi-Strauss 1949: Chapter V). Reciprocity secures the bond within the social groups and regulates the relationships between them. It also remains present after the coming into existence of political rule: Stable political power can never be based on mere violence, but must bring some advantages to the governed. The acceptance of rulership with all its prerogatives presupposes a return service. ${ }^{9}$ Yet, rulership shows a constant tendency to set itself free from this consensus and fall into despotism. This experience is reflected in the political philosophy of axial age China, when philosophers rediscover the topic of reciprocity and make it the center of their theories. They remind the powerful that the ruled are human beings with feelings and expectations like themselves and should be treated as such. Legitimate power has to adhere to the standard of a just give and take. It comes as no surprise that the early formulations of the Golden Rule are often to be found in a political context - the ruler "should not do to others what he does not wish for himself" and "should not inflict onto others what he does not feel comfortable about himself." (Guanzi 51:275, 66:341) When Zhou literature keeps on repeating that subordinates will behave just as their superiors do and retaliate what is done to them, this is a reminder of the expectation of reciprocity. ${ }^{10} \mathrm{In}$

${ }^{9}$ For some examples of this conviction from ancient Chinese texts cf. Roetz 1993:36.

$10 \mathrm{Cf}$. for example Mengzi 4A21 and 4B5: "If the ruler is humane, everybody will be humane. And if the ruler is just, everybody will be just." - "If the ruler regards his subjects as his hands and feet, they will regard him as belly and heart. If the ruler regards his subjecis as his dogs and horses, they will 
ancient China, this has not led to the idea of a judicial protection of equal rights. But the foundation for such a step is laid - the acknowledgment of equal membership of all in a community. Human rights can be seen as the final judicial form of this acknowledgment, while the Golden Rule is its moral form. In this sense, reciprocity as the structural basis of all human existence is the original wellspring of human rights, and to build a political philosophy on this basis is not principally removed from their recognition.

Another check on political power in Chinese axial age philosophy is exerted by a moral anthropology that in tendency treats humans as subjects in the sense of being bearers of certain claims even before entering into relations with others that have to be respected: the moral anthropology of Mengzi. Mengzi bases his program of a "humane politics" (ren zheng) on the conviction that every human being is, by virtue of his heavenly endowed natural inclinations (xing), not only capable of but also spontaneously driven to moral judgment and action. For together with the feeling of compassion, the feeling of shame, the feeling of modesty, and the feeling of right and wrong, the "four beginnings" (si duan) of humaneness, justice, propriety and moral knowledge are innate to the human being (Mengzi 2a:6, Roetz 1993:200). These "beginnings" exist as our "good knowledge" (liang zhi) and our "good capacity" (liang neng) before any deliberation and learning (Mengzi 7a:15, Roetz 1993:130), simply by virtue of being a human and independent of social position or achievements. They are "not cast into us from outside, we have them in ourselves originally." (Mengzi 6a:6)

For Mengzi, a "humane politics" is a politics that "cannot bear to see the suffering of others." (Mengzi 2a:6) By grounding the possibility for such a politics in the natural disposition, Mengzi can exert pressure on the powerful—nobody can talk his way out by declaring himself incapable of morality. However, the point of his anthropology is not only to prove the powerful guilty of violating their moral nature when they neglect their duties and behave like murderers and robbers rather than ideal kings. Obviously, Mengzi is also convinced that the same fact that obliges the actor to moral action, the moral nature endowed by Heaven which distinguishes a human from a beast, also constitutes a claim on the other side - the side of those affected by the actions - to be treated as humans. As he says to King Hui of Liang,

"When there is fat meat in the [king's] kitchen and there are fat horses in the stables, but the people have the look of hunger and die by starvation out in the countrythis is as if letting the beasts devour men! Men already despise the beasts for devouring one another. But when a prince, being father and mother to his people, administers his government in such a way that he lets beast devour men, where is then his being father and mother to the people?' When Confucius said, 'He who first made tomb figures to be buried with the dead should be without posterity!', he said so because that person 
used (instrumentalized!) men by making semblances of them. What should then be thought of him who causes his people to die of hunger?" (Mengzi 1a:4) ${ }^{11}$

Although we can call Mengzi's ethics primarily duty-oriented, there is an obvious complementarity here of a duty on the side of the king and a moral quasi-right on the side of the people: they do not deserve to be treated worse than beasts. In another passage, Mengzi praises a king who shows compassion with a trembling ox being led to ritual slaughter as "humane", but at the same time expresses astonishment why the king does not extend such an attitude to the people (Mengzi 1a:7). This shows that the morality of an action follows not only from the intentions of the actor, but from the correspondence of the intentions with the nature of the object - an act of compassion can also be aimed at an animal, but it has its true place among human beings. And what makes the human being stand out in comparison with an animal is the moral propensity which enables one to resist the desire for profit ( $l i$ ) and even to give one's life for justice. Even a beggar, Mengzi says, refuses the gift that would save his life, if he receives it with a kick (Mengzi 6a:10, Roetz 1993:153-154). The beggar example suggests that this uniqueness of the human being is linked to the idea of dignity. As a matter of fact, the notion of dignity becomes explicit in Mengzi's ethics.

According to Mengzi, human nature represents an intrinsic "dignity" (gui) prior to any other external dignity that might be conferred by state and society. As he says in his polemic against the powerful of his time, "To desire dignity (gui) is an aspiration all men have in common. But every single human has something dignified within himself which he only does not think of. What men [normally] esteem as dignity is not the good dignity (liang gui). Whom [a potentate like] Zhao Meng can honor, Zhao Meng can also degrade." (Mengzi 6a:17)12 In accordance with this argument, Mengzi has placed the "heavenly ranks" (tian jue) of morality with "humaneness" (ren) at the top above the "human ranks" (ren jue) of the political hierarchy in the preceding passage (Mengzi 6a:16, Roetz 1993:196).

That a human is a being to be respected by the powerful instead of being treated like an animal is obviously due to this "good dignity" of human nature. The autonomous capability of judging and acting morally (the liang zhi or shi fei zhi xin) should still be fostered by education, but does not justify external tutelage. According to Mengzi, it is above all for political reasons if this capability falls by the wayside in practice. For instead of providing optimal conditions for their subjects to unfold their intrinsic natural goodness, rulers by their disastrous policy and greed drive them into misery and force them into crime. In this case, however, it would amount to "trapping" people to penalize them for their offenses - the ruler loses his right to punishment (Mengzi 1a:7, 3a:3). The claim to loyalty and allegiance, too, is bound to a return ser-

11 The critique of using tomb figures in the shape of human beings was probably motivated by the assumption that this led to the practice of human sacrifice in burial.

12 Möller (1999:117-118) has criticized the translation of gui with "dignity" as causing false associations. I am convinced, however, that the associations, the difficulties that the text poses notwithstanding, are not misleading. For a discussion of Möller's argument cf. Roetz 2008:105-106. 
vice. Thus Mengzi justifies the refusal of the people of Zou to die in war for their superiors who had previously maltreated them (Mengzi 1b:12, Roetz 1993:78). Mengzi's teaching of man's innate moral goodness subsequently provided the main theoretical and rhetorical foundation for the critique of despotism in China (de Bary 1988, Ommerborn, Paul and Roetz 2011). In contemporary "New-Confucianism", it is still the most important point of departure in order to develop Confucian political philosophy in the direction of human rights and democracy (Li 1995 and 2002). ${ }^{13}$

However, there is a difficulty in Mengzi's approach that has to be considered: Speaking of the "dignity" of "human nature" (xing) is not identical with speaking of the dignity of the human being. It can at first glance not be ruled out that dignity is only then transferred to the human being if he or she acts in accordance with the moral nature. There is an ambiguity here in the Mengzi that reappears today in some "New Confucian" attempts to link the enjoyment of human rights to the actual performance of virtuous acts. ${ }^{14}$ As a matter of fact, Mengzi says that man in practice can demean himself to such a degree as to resemble an animal (Mengzi 3a:4, 4b:19, 4b:28, 6a:6). But he also explicitly stresses that this does not affect man's "true condition" (qing): "When others see him being brutish, they think that there was never any talent in him. But how would this be man's true condition!" (Mengzi 6a:6) There is a never changing "true condition" of the human being, then, which can always be revitalized if only one "seeks for it." (Ibid.) A human would not be defined by performance or achievements, then, but by moral possibilities. This is exactly what the "four beginnings" mean, which every human being has within himself in the very same way as he possesses his "four limbs." (Mengzi 2a:6)

Mengzi speaks of dignity, then, with regard to the general moral potential of the human being. It is this potential from which not only the individual, but also the state should take its orientation. The autonomous capability of morality does not justify excessive employment of state enforcement and sanctions but, reversely, calls for a modest policy that directs all its activity to protecting and supporting the natural goodness of man. A human is worthy of being free from subjugation under the state's coercing whim. Mengzi's ancient critics are clearly aware of the "dangerous" implications of this anthropology: They reproach him for calling into question the necessity of education and the "principle of government", and for betraying the tradition-if the human being is "good" in itself, one no longer needs the sages of the past (Roetz 1993:221222).

In fact, Mengzi himself was not willing to draw such radical conclusions from his philosophy - in many respects he is a child of his time. Like all pre-modern Confucians, he is a monarchist and elitist and tends towards a benign paternalism. Moreover, he is intolerant of other opinions. Therefore, when it comes to developing his philosophy

13 Based above all on the Mengzi, Lee Ming-huei has convincingly argued that individual rights in particular rather than collective rights are compatible with Confucianism. He thus reverses the "official“" Chinese order ( $\mathrm{Li} 2002)$.

14 Cf. the examples discussed in Roetz 2002, p. 316 
to find a starting point from where a virtual Chinese prehistory of the ideas of human rights can be written, one has to think with him against him. Nevertheless, such a development is possible: In line with the suspicion of his critics, Mengzi's moral anthropology in principle opens up a perspective which surpasses what was within his own imagination: The perspective of a free democratic state that treats humans as mature and self responsible citizens, relying on their autonomous competence of judgment, and protecting them from any bullying by institutions.

What is more, Mengzi's ethics would mutatis mutandis not only deliver a theoretical Confucian basis for the acknowledgment of human rights. Anthropological assumptions like his might even be a conditio sine qua non for justifying the idea of human rights in the first place: If a human were no more than a rationally calculating egoist, guaranteeing human rights would amount to giving wings to the tiger, and the strategic derailment of any promotion of human rights would be preprogrammed. This is an important critical point in the human rights problematique which probably also helps explain the Western history of gross human rights abuses. That the one culture which takes pleasure in declaring human rights part of its identity could at the same time be their greatest violator is perhaps more than a deplorable inconsistency. It might have to do with the understanding of the holder of rights as a "possessive individualist" (Macpherson 1962), 15 an "isolated monad secluded in itself" (Marx 1976:364), ${ }^{16}$ primarily obliged to his or her self-interest, which has exerted a sustained impact on modern political, economic and, last but not least, legal thought to this day. It comes as no surprise that the right to private property figures prominently in human rights catalogues, and it is revealing that the connection between both is also visible in the revised Constitution of the People's Republic of China, where the gates have been opened to an extreme form of capitalism. Obviously, modern "subjectivity" has a double if not contradictory face, which also becomes apparent in the ambivalent meaning of "autonomy": It can, with Kant, refer to the free submisson to the moral law, but is can also refer to self-determination in general. The acknowledgment of subjectivity is the indispensable precondition of political, social and cultural freedom, but it has a negative side which already sparked opposition at an early stage: It can foster acquisitive individualism with the tendency to make the rationality of means and ends the dominant form of rationality and the calculated contract the dominant form of social relations. Thus it might not exhibit a sufficient power of cohesion to prevent society from drifting apart (Hegel: Entzweiung). This has given rise to the backward-looking temptation to curb

15 Possessive individualism is according to Macpherson (1962:269) based on the following premises: "Individuals are by nature equally free from the jurisdiction of others. The human essence is freedom from any relations other than those that a man enters with a view to his own interest. The individual's freedom is rightly limited only by the requirements of others' freedom. The individual is proprietor of his own person, for which he owes nothing to society." (Italics added)

16 As Marx says (ibid.), "The human right of freedom is not based on the connection of man and man, but on the separation of man from man. It is the right of this separation, the right of the reduced individual, reduced to himself." 
subjectivity again by a reestablished organic form of community with authoritarian institutions and a corresponding constraint on human rights.

If one wants neither to subscribe to this conservative solution nor to the disastrous unfolding of "rugged individualism", one would have to specify the notion of subjectivity in such a way that the self-sufficient autarky of the individual is suspended without rescinding its claim to autonomy and authenticity, which irrevocably remains part of any society that can call itself "modern". Hegel and Marx have already made a step in this direction (Hook 1936: 41ff.). The "classical" answer to the question has been given by American pragmatism with the transformation of the paradigm of subjectivity into the paradigm of intersubjectivity. It implies that autonomy, rather than being an innate quality of the human being, becomes a function of human relations and is, therefore, less prone to a solipsistic reduction-we owe it to the other. ${ }^{17}$ Rights would not be something one "possesses" as one's private property, but they would be the juridical form of a mutual recognition without which human beings would not be what they are and would not have what they have. To remind of this indebtedness to the others can, at least in theory, forestall the enjoyment of rights at the expense of the commitment to the human community; it demands from us the "intertwining of autonomy and devotion" (Habermas 1992:122).

Contemporary Confucian literature often asserts that Confucianism, too, has consistently avoided isolating the individual and always thought in the relational paradigm (cf. e.g. Tu 1985). The argument is routinely politically exploited for legitimizing the subordination of the individual under an external authority. As mentioned above, Western sinology has also tended to present Confucianism as a collectivistic ethics without a notion of a human "subject". However, the Mengzi shows that the picture is much more complicated and that Confucianism is in fact closer to a philosophy of subject (Subjektphilosophie) than the stereotype tell us. A "Mencian" solution to the problem we are discussing would, more in line with Western natural law philosophy than with the paradigm of intersubjectivity, draw on the "true condition" or "essence" of a human as an ens morale rather than a mere homo oeconomicus by nature. This, too, would forestall the loss of commitment to the common weal that can accompany the enjoyment of individual rights and has in fact been one source of anti human rights polemic. Right would be tied to morality as its original source. The modern Confucian philosopher Mou Zongsan (1909-1995) has developed Mengzi's ethics in this direction by introducing the idea of a "self-restriction" or "self-negation" (ziwo kanxian) of what Mengzi, as mentioned above, calls the innate moral "good knowledge" (liang zhi) (Mou 1961:55ff.):18 The "good knowledge," which primarily informs us about our moral duties, restrains itself in order to leave ample scope for right. Right is not the abdication of morals, then. It is a moral obligation in itself to organize the protection of human

${ }^{17}$ I have discussed the pragmatist position as it has been developed by Charles S. Peirce and in particular George-Herbert Mead in connection with the sinological debate on Confucian ethics in Roetz 2013.

18 For a discussion of Mou's theory, cf. Chen 2007 
dignity by making rights share equal space with duties rather than exclusively rely on duty-consciousness. This division of labor would bring to light a complementarity of duties and rights that is already implicit in the duty-centered model.

I sympathize with this derivation of rights from morals, provided that it does not result in making the enjoyment of rights dependent on the performance of virtuous acts $^{19}$ (see above) rather than on the general human capability to perform such acts: a human deserves rights not because he or she verifiably fulfills duties, but because he or she, as a human, is able to fulfill duties. Furthermore, a human needs rights in order to ensure that acting morally does not amount to an imposition, as is the case in an unjust world where many have to live in misery and, forced below the breadline, often enough have to become criminal in order to survive - as Mengzi, the moralist, already knew. ${ }^{20}$

Nevertheless, the Mencian model delivers only a necessary, but not a sufficient basis to obtain moral norms from where in turn legal norms can be generated-it seems to overstretch the normative capacity of human nature. In this model, human sociality has only a supportive, but not a generative role for morality, which is already innate to the human being in the form of dynamic "beginnings". This delivers a counter argument against reducing the human being to the "possessive individualist" who calculates his personal benefits. At the same time, it delivers a strong notion of a human person or subject furnished with self-consciousness in awareness of its autonomous capacities. The Mengzi is replete with proud manifestations of unyieldingness and independence of the moral actor from political patronage - if necessary, he will "stride his way alone" and not "bend to authority and power". ${ }^{21}$ This strong notion of an autonomous subject, though with elitist overtones not fully consistent with the egalitarian dimension of Mengzi's moral anthropology, is certainly an asset when it comes to reconstructing Confucian ethics in accordance with the human rights idea. However, the Mencian model does not call into question the very framework of Subjektphilosophie itself which in principle also covers the strategic form of subjectivity described by Macpherson. The Mencian approach is closer to its rival than it appears at first sight: both appeal to something that the individual has or possesses - natural morality or natural rights-prior to society. There is no attempt made to explore intersubjectivity as a source of solidarity - it is only taken into account as an ethical responsibility or as a strategic factor, but not (at least not sufficiently) as the medium to which the moral as

19 This suspicion leads Yu Kam Por's to abandon the Mencian model, since, as he sees it, because of its moral emphasis it might actually be a hindrance to actively claiming rights. Unlike most Confucian philosophers, he refers to Mengzi's Confucian critic Xunzi in order to find a basis for a Confucian conception of human rights (Yu 2005, Roetz 2005a).

${ }^{20}$ Cf. Mengzi 1a:7: "As to the people, without a fixed livelihood, they will not have a fixed heart. And without a fixed heart, there is nothing they will not do, be it self-abandonment, devious conduct, depravity or extravagance. When they thus have fallen in crime to punish them accordingly - this is to entrap the people. How can such a thing as entrapping the people be done with a humane ruler on the throne?"

${ }^{21}$ Mengzi 3b:2, Roetz 1993:172. For other impressive examples from the Mengzi and other Confucian texts cf. Roetz 1993:81-89 and 172-174. 
well as the calculating self owes its very constitution. The interrelatedness of the ego with the other is well expressed in the Golden Rule-I find the right way to act as soon I recognize myself as an element in a reciprocal relationship with my fellow humans. But it is characteristic that, in contrast to Confucius, in Mengzi's ethics the Golden Rule does not play a major role, if any22 - the "good knowledge" already tells us what to do before we realize ourselves as relational beings. Herewith, the moral qualification notwithstanding, Mengzi does not abandon the self-referential subjectivism that also informs the "possessive individualist". This suggests a step beyond the Mencian model: In order to transcend and at the same time "sublate" (aufheben) the subjectivistic paradigm, the two prominent readings of the central virtue of "humaneness" (ren) in Confucianism in terms of the Golden Rule and innate benevolence would have to be integrated in such a way that the subjects are neither led into a new bondage nor renounce their responsibility for the common interest. This means that a strong notion of the subject as implicit in Mengzi's moral anthropology remains important. It is a necessary gateway to and element of a philosophy of intersubjectivity that takes into account the social constitution of the individual without subsuming it under the dominance of the collective.

The problems that I have discussed in the last part of my paper with regard to the naturalistic foundation of Mengzi's ethics are reminiscent of similar ones in the European natural law tradition which, after all, was a powerful driving force for the development of the human rights idea. They refer to internal problems of the philosophical foundation and justification as well of the practice of human rights about which there is no unanimous consensus and do not in the least affect the main thesis that I would like to defend: that China delivers an excellent example of the possibilities at hand in a nonWestern intellectual tradition in order to support the acknowledgment of human rights of the individual against the state. ${ }^{23}$ It is not the case that China would prove the cultural limits for such an acknowledgement. Generally speaking, the problem lies not with the cultural traditions but with the way we position ourselves relative to them and what we make out of them under modern conditions. There is certainly no historical culture that, measured by the standard of human rights, would not deserve to be under critique - in this case, the idea of human rights would never have appeared and gained currency. But there is also no culture that would not have at its command the means to critically reflect on itself and agree on or generate new norms, if necessary-the more so, if these norms are rooted in the deep structures of human society as such. There is no cultural license, there is only political accountability for the denial of human rights.

22 Cf. Roetz 1993:146-147.

23 In this article, I have referred primarily to Confucian literature. For arguments concerning the compatibility of human rights with Daoism ef Schweidler 1999. 


\section{Bibliography}

American Anthropological Association (1947): "Statement on Human Rights," Submitted to the Commission on Human Rights, United Nations, by the Executive Board, American Anthropological Association, in: American Anthropologist, New Series, Vol. 49,4, pp. 539-43.

Ames, Roger T. (1988): "Rites as Rights: The Confucian Alternative," in: L. S. Rouner, ed., Human Rights and the World's Religions, Notre Dame: University of Notre Dame Press, pp. 199-216.

Angle, Stephen, and Marina Svensson, eds. (2001): The Chinese Human Rights Reader: Documents and Commentary, 1900-2000, Armonk, N.Y.: M. E. Sharpe.

Bauer, Wolfgang (1994): "Mensch, Natur, Fremdheit: Die Idee der Toleranz im Alten und Neuen China," in: Ingrid Krüssmann et. al., eds., Der Abbruch des Turmbaus: Studien zum Geist in China und im Abendland, Nettetal: Steyler Verlag, pp. 39-58.

Bellah, Robert (2011): Religion in Human Evolution. From the Paleolithic to the Axial Age, Cambridge, Mass.: Belknap of Harvard University Press.

de Bary, Wm. Theodore (1988): "Neo-Confucianism and Human Rights," in: L. S. Rouner, ed., Human Rights and the World's Religions, Notre Dame: University of Notre Dame Press, pp. 183-198

Chen, Albert H. Y. (2007): "Is Confucianism Compatible with Liberal Constitutional Democracy?", Journal of Chinese Philosophy 34,2, pp. 196-216.

Deng Xiaojun (1995): Rujia sixiang yu minzhu sixiang de luoji jiehe (The logical link between Confucian and democratic thought), Chengdu: Sichuan renmin chubanshe.

Guanzi, Zhuzi jicheng, vol. 5, Hong Kong: Zhonghua, 1978.

Guowuyuan xinwenbangongshi (Information Office of the People's Republic of China, Council of State) (1991): Zhongguo de renquan zhuangkuang (The situation of human rights in China), Beijing.

Habermas, Jürgen (1992), Texte und Kontexte, Frankfurt/M.: Suhrkamp.

Hall, David, and Roger Ames (1988): The Democracy of the Dead, Chicago and Lasalle: Open Court.

Hook, Sydney (1936): From Hegel to Karl Marx, London: Victor Gollancz.

Lévi-Strauss, Claude (1949): Les structures élémentaires de la parenté, Paris: Presses Universitaires de France, 1949.

Li Minghui (Lee Ming-huei) (1995): "Xingshanshuo yu minzhu zhengzhi” (The theory of the goodness of human nature and democratic politics) in: Liu Shuxian, ed., Dangdai ruxue lunji: tiaozhan yu huiying, Taipei: Zhongyang yanjiuyuan, pp. 159-198.

Li Minghui (Lee Ming-huei) (2002): "Rujia chuantong yu renquan" (Confucian tradition and human rights), Yuandao 7, pp. 36-55.

Lunyu (Analects), Harvard-Yenching Sinological Index Series, A Concordance to the Analects of Confucius, reprint Taipei 1972.

Lüshi chunqiu, Zhuzi jicheng, vol. 6, Hongkong: Zhonghua, 1978.

Macpherson, C. B. (1962): The Political Theory of Possessive Individualism. Hobbes to Locke, Oxford: Oxford University Press.

Marx, Karl (1976): “Zur Judenfrage,” in: Marx Engels Werke, vol. 1, Berlin: Dietz. 
Mauss, Marcel (1966): The Gift: Forms and Functions of Exchange in Archaic Societies, translated by Ian Cunnison, London: Cohen \& West

Mengzi, Harvard-Yenching Sinological Index Series, A Concordance to Meng Tzu, Reprint Taipei 1973.

Möller, Hans-Georg (1999): "Menschenrechte, Missionare, Menzius. Überlegungen angesichts der Frage nach der Kompatibilität von Konfuzianismus und Menschenrechten," in: Gunter Schubert, ed., Menschenrechte in Ostasien, Tübingen: Mohr, pp. 109-122.

Mou Zongsan (1961): Zhengdao yu zhidao (Politics and administration], Taipei: Guangwen shuju.

Mozi, Zhuzi jicheng, vol. 4, Hongkong: Zhonghua, 1978.

Müller, Sven-Uwe (1997): Konzeptionen der Menschenrechte im China des 20. Jahrhunderts, Hamburg: IfA.

Nie Jingbao (2011): Medical Ethics in China: A Transcultural Interpretation, London: Routledge.

Ommerborn, Wolfgang, Gregor Paul and Heiner Roetz (2011): Das Buch Mengzi im Kontext der Menschenrechtsdebatte, Münster: LIT.

Roetz, Heiner (1993): Confucian Ethics of the Axial Age, Albany: SUNY Press.

Roetz, Heiner (2002): "Rights and Duties: East/West," in: Karl-Heinz Pohl and Anselm W. Müller, eds., Chinese Thought in a Global Context: Moral Bases of Contemporary Societies. Leiden: Brill, pp. 301-317.

Roetz, Heiner (2005): "Tradition, Moderne, Traditionskritik. China in der Diskussion," in: Torsten Lalbig and Siegfried Wiedenhofer, eds., Kulturelle und religiöse Traditionen. Beiträge zu einer interdisziplinären Traditionstheorie und Traditionsanalyse, Münster: LIT, pp. 124-167.

Roetz, Heiner (2005a): "Commentary on Kam-por Yu, 'Human Rights and Cultures'," in: Ludger Kühnhardt and Mamoru Takayama, eds., Menschenrechte, Kulturen und Gewalt. Ansätze einer interkulturellen Ethik, Baden-Baden: Nomos, pp. 77-82.

Roetz, Heiner (2008): "Die Kritik der Herrschaft im zhouzeitlichen Konfuzianismus und ihre aktuelle Bedeutung," Deutsche China Gesellschaft, Mitteilungsblatt 1/2008, pp. 95-107.

Roetz, Heiner (2009): "Tradition, Universality and the Time Paradigm of Zhou Philosophy," Journal of Chinese Philosophy, 36.3, pp. 359-375.

Roetz, Heiner (2009a): "The end of ethical universalism? Bioethics in the age of globalization and the case of China," in: Beat Sitter-Liver, ed., Universality: From Theory to Practice, An intercultural and interdisciplinary debate about facts, possibilities, lies and myths, Fribourg: Academic Press, pp. 177-190.

Roetz, Heiner (2011): "Transfer in Dispute. The Case of China," in: Jörg Feuchter et. al., eds., Cultural Transfer in Dispute. Representations of Asia, Europe and the Arab World since the Middle Ages, Frankfurt/New York: Campus, pp. 273-276.

Roetz, Heiner (2012): "The Axial Age Theory between Philosophy and Religion, Sociology and History. With a Look at the Normative Discourse in Axial Age China," in: Robert N. Bellah and Hans Joas, eds., The Axial Age and its Consequences, Cambridge Mass. und London: Belknap, Harvard UP, pp. 248-276. 
Roetz, Heiner (2013): “A Comment on Pragmatism and Chinese Studies," in: Yang Chen-te, ed., Confucianism in East Asian Perspective: Modern Responses, Taipei: Academia Sinica, forthcoming.

Rosemont, Henry (1988): "Why Take Rights Seriously? A Confucian Critique," in: L. S. Rouner, ed., Human Rights and the World's Religions, Notre Dame: University of Notre Dame Press, pp. 167-182.

Schrey, H.-H. (1983): "Wiedergewinnung des Humanum? Menschenrechte in christlicher Sicht," Theologische Rundschau 48, pp. 64-83.

Schweidler, Walter (1999): "Unsagbare Freiheit. Ist der Daoismus mit der Menschenrechtsidee vereinbar?", in: Josef Thesing and Thomas Awe, eds., Dao in China und im Westen. Impulse für die moderne Gesellschaft aus der chinesischen Philosophie, Bonn: Bouvier, pp. 268-289.

Sun Yatsen (1973): "San min zhuyi, minquan zhuyi, dier jiang" [1925], in: Sun Zhongshan xuanji, vol. 2, Hongkong: Zhonghua.

Tu Wei-ming (1985): "Selfhood and Otherness in Confucian Thought," in: Anthony J. Marsella, ed., Culture and Self: Asian and Western Perspectives, New York: Tavistock.

von Senger, Harro (1997): "Die Ausgrenzung Hongkongs aus dem europäischen Menschenrechtsschutz," in: Gregor Paul and Caroline Robertson-Wensauer, eds., Traditionelle chinesische Kultur und Menschenrechtsfrage, Baden-Baden: Nomos, pp. 91-116.

Walf, Knut (1990): "Evangelium, Kirchenrecht und Menschenrechte: Begründung und Defizite," Concilium 26:2, pp. 112-118.

Yu Kam Por (2005): "Human Rights and Cultures," in: Ludger Kühnhardt, ed., Menschenrechte, Kulturen und Gewalt : Ansätze einer interkulturellen Ethik-Human rights, cultures and violence : approaches to intercultural ethics, Baden-Baden: Nomos, pp. 65-76

Zhang Junmai (1981): Zhong Xi Yin zhexue wenji (Essays on Chinese, Western and Indian Philosophy), vol. 1, Taipei: Xuesheng shuju. 